\title{
EVALUATION OF FACTORS AFFECTING DENTAL ANXIETY IN ADOLESCENTS
}

\begin{abstract}
Objectives: Dental anxiety determines the frequency of dental treatment availed with long-term implications in oral health maintenance. The aim of this study is to investigate the effects of sociodemographic data, dental anxiety levels of parents, family functionality, perceived family support and other associated factors on dental anxiety of adolescents.
\end{abstract}

Materials and Methods: 213 adoloscents who applied to the Pediatric Dental Clinic and their parents were included in the study and their sociodemographic data were recorded. The Corah Dental Anxiety Scale was applied to the adolescents and their parents to determine dental anxiety and the Perceived Family Support Scale was applied to measure the perceived family support of the adolescents. Regarding the family functionality, the parents answered the Family Assessment Device.

Results: The avarage dental anxiety level of the adolescents was $8.87 \pm 3.10$. The family functions were unhealthy in terms of roles, and affective involvement. According to the multiple regression analysis, the predictors of dental anxiety levels were family functionality, maternal educational level, previous application to the dentist, having negative experience in the past, the choosing of a dental treatment center, and training regarding dental treatment.

Conclusions: Clinicians should consider that socio-cultural characteristics, family functionality and support may affect dental anxiety, and the improvement of the physical environment may be effective in reducing dental anxiety during dental treatment of adolescents.

Keywords: Adolescents, dental anxiety, family functionality, perceived family support, sociodemographic factors.
*Eda Arat Maden ${ }^{1}$

(D) Özgür Maden ${ }^{2}$

(D) Barış Karabulut ${ }^{3}$

(D) Günseli Güven Polat ${ }^{3}$

ORCID IDs of the authors:

E.A. $\quad 0000-0003-2562-3928$

Ö.M. 0000-0002-0430-5747

B.K. $\quad 0000-0001-5556-3237$

G.G.P. $\quad 0000-0003-1228-1260$

${ }^{1}$ Department of Pediatric Dentistry, Center of Oral and Dental Health, Taksim Training and Research Hospital, Istanbul, Turkey.

${ }^{2}$ Clinic of Mental Health and Disease, Health Science University Sultan 2. Abdulhamid Khan Training and Research Hospital, Istanbul, Turkey.

${ }^{3}$ Department of Pediatric Dentistry, Health Sciences University Faculty of Dentistry, Istanbul, Turkey.

Received : 23.04.2021

Accepted : 01.07 .2021 


\section{INTRODUCTION}

Dental anxiety is defined as the fear and concern an individual feel against any dental process without being associated with private external stimulant. ${ }^{1}$ Dental anxiety is known to be related with multiple psychosocial factors, i.e. it is a problem in which social factors and individual thoughts and behaviors are related to each other. ${ }^{2}$ Although it is seen at all ages, it generally appears in childhood and adolescent periods. Dental anxiety affects 10 to $20 \%$ of adults and $43 \%$ of children and adolescents. ${ }^{3,4}$ Anxiety is an important problem in the dental care of children and adolescents. Dental anxiety often causes avoidance of dental care, and can cause serious deterioration in oral and dental health. Such a deterioration can significantly increase dental care costs. For this reason, reducing anxiety is important in terms of patients, doctors and costs.

Many factors like age, gender and sociodemographic factors were reported to be effective in dental anxiety. ${ }^{5-8}$ Some authors recommend a classification for the reasons of children's dental anxiety - intrinsic factors (i.e. age, temperament), external family factors (i.e. family anxiety, socioeconomic status), and external dental factors (i.e. dental and medical experience). ${ }^{2}$ One of the most important internal factors regarding children's dental anxiety is age. Some authors reported that although there was a decrease in anxiety levels, it was not linear. ${ }^{9,10}$

The role of families is also important in the formation of anxiety in children and adolescents. Epstein and Bishop defined families that can solve problems as those coming together, those being emotionally connected to each other and those not preventing each other's freedom, everyone can effectively perform the role expected of him/her, control each other's behaviors in a way that does not overdo, and families with a comfortable and direct communication functions as healthy families. ${ }^{11}$ Families who perform their functions at the expected level are functional families. Families who cannot perform their functions because of impaired domestic interaction were defined as non-functional families. The most important characteristic of a "non-functional" family is that the communication function is corrupted, and interpersonal relations are broken, and are subject to rules. ${ }^{12}$ It was determined that adolescents in families who engage in negative attitudes and behaviors have high anxiety levels. ${ }^{13}$ To more fully understand adolescent dental anxiety, examination of family functionality is critical.

Social support that is perceived from the family makes individuals feel good in spiritual terms, increase their confidence, and help them develop positive self-esteem and selfawareness. Social support also prevents stress and anxiety, and also has an effect on the problem-solving skills of the individual. ${ }^{14}$ In this context, it can be speculated that it is important to investigate the relations between social support and family functionality perceived from the family, and the effects of these on dental anxiety.

In general, children and adoescents who have dental anxiety try all means to avoid or delay dental treatment, which causes deterioration of oral health. ${ }^{15}$ In addition, they also show poor cooperation during dental visits, which jeopardizes the treatment outcomes, creating occupational stress on the dentist and a dispute between the dentist and the parents. ${ }^{16}$ Dental anxiety in childhood and puberty continue in adulthood, leading to the avoiding of dental treatment; and as a result, oraldental health is adversely affected. ${ }^{7,17}$ Adolescents with dental anxiety had negative thoughts regarding their dental and general health. ${ }^{18}$

Adolescence may represent a developmental period in which dental fear/anxiety can have a disproportionate effect on future dental attendance or avoidance behavior. Dental anxiety in adolescence is a critical period for the development of independence in decision-making and control emerged as an important factor of dental fear / anxiety in this period ${ }^{19}$, and it is worth examining as it complicates its etiology and potential future impact. Considering the not so adequate and contradictory evidence, in the present study it was aimed to determine whether there is a difference between the dental anxiety levels of the adolescents according to the sociodemographic data of the participants and whether there is a relationship between the dental anxiety levels of the families and the dental anxiety levels of the adolescents, and familial factors such as family functionality and 
perceived family support in relation to the previous experiences in dental treatments. In addition, it was aimed to determine whether these variables are predictors of adolescents' dental anxiety levels.

\section{MATERIALS AND METHODS}

This study was conducted with 213 parents and adolescents between the ages of 13 and 16 who applied to Taksim Education and Research Hospital, Gumussuyu Children's Dentistry department, and Health Sciences University, Sultan Abdulhamid Khan II, Education and Research Hospital between January 2019 and July 2019. Simple random sampling method was preferred in the selection of the study group. Ethical permission required for the study to be carried out was obtained from Health Sciences University, Medical Research Local Ethics Board (decision no: 18/69- decision date: 26/10/2018). All procedures of the presented research were performed based on the Declaration of Helsinki. After two pedodontists informed the participants about the study and obtained the required permissions, the forms and scales that were prepared by the researchers were given in line with the desired information, and the participants were asked to complete these forms in full. Those with any immediate treatment requirement, and those with mental physical and/or systemic disease were not included in the study. The questionnaires took about 20 minutes to complete.

\section{Data Collection}

\section{Socio-demographical Data Form}

It was developed by the researcher and filled in by the parents to determine the sociodemographic characteristics of the participants, such as age, gender, education and income status of their parents. This form also included questions about previous application to the dentist, having negative experience in the past, choosing a dental treatment center, and training regarding dental treatment.

\section{Corah Dental Anxiety Scale (DAS)}

The translation of this scale into Turkish and its validity and reliability study were conducted by Seydaoglu et al. ${ }^{20}$ This scale was filled by adolescents and their families. The scale consists of four questions and is scored between 1-5 points. The total score obtained from the scale ranges from 4-20. According to this scale, a total score of less than 13 points show low anxiety, 13-14 show moderate anxiety, and 15 and above show high anxiety.

\section{Family Assessment Device (FAD)}

The McMaster Family Assessment Device (FAD), a questionnaire developed to evaluate families according to the McMaster Model, consists of seven scales that measure problem solving (PS), communication (CM), roles (RL), affective responsiveness (AR), affective involvement (AI), behavior control (BC) and general functioning (GF). Its validity and reliability study was done by Epstein et al. ${ }^{21}$ and adaptation to Turkish was done by Bulut. ${ }^{22}$ This scale was filled in by the parents. The total score of the scale consisting of 60 items varies between 1-4 points. If the family's score in an area exceeds 2 , it is considered to be a problem in that area and indicates that the family function in that area is unhealthy. The scale does not have a total score and subscales are evaluated separately.

\section{Perceived Family Support Scale (PFSS)}

This scale, which is used to evaluate perceived family support, was developed by Procidano and Heller, and was adapted to Turkish by Eskin. ${ }^{23}$ This scale was filled by the adolescents. The scale consists of 20 questions which are answered as "Yes", "No", and "Partly". The 3rd, 4th, 16th, 19th and 20th questions of the scale are scored with 2 (Yes), 0 (No), and 1 (Partly), and all other questions are scored as 0 (No), 2 (Yes), and 1 (Partly). The total score of the scale varied between 0-40. Increased scores show good family support.

\section{Statistical analysis}

The statistical evaluations were made by using the SPSS (ver. 22.0. Chicago. II. USA) program. The resulting data were transferred to computer medium. While evaluating the findings obtained in the study, mean, standard deviation, and frequency were used in descriptive statistics. Kolmogorov-Smirnov test for the normal distribution fit of quantitative data, Chi-square test for comparison of categorical variables, Independent sample t-test for comparison of means of numeric variables, and Pearson correlation analysis for determining the relationships between variables were used. Multiple regression analysis was used to determine the factors predicting the dependent variable. Results were 
evaluated at $95 \%$ confidence interval and significance level of $\mathrm{p}<0.05$.

\section{RESULTS}

Most of the adolescents participating in the study $(55.9 \%, \mathrm{n}=119)$ were girls, and the mean age was $14.36 \pm 1.12$. When the socio-demographical data of the parents and the adolescents were evaluated, the mean age of the mothers was $40.00 \pm 5.07$, the mean age of the fathers was $44.39 \pm 4.84$ and the mean age of the adolescents was $14.25 \pm 1.13$. A majority of the mothers $32.9 \%(\mathrm{n}=70)$ had 1-4 years of education, and a majority of the fathers $32.4 \%(n=69)$ had $9-12$ years of education. A large portion of the family income $(83.6 \%)$ could be described as families having middle income. $93.4 \%$ of the adolescents $(\mathrm{n}=199)$ had previously referred to dentists, and $12.7 \%(\mathrm{n}=27)$ had negative experience in the past. Of the adolescents, 53.5\% ( $\mathrm{n}=114)$ had recent toothache. $35.7 \%$ of the adolescents $(n=76)$, applied to a state hospital, and $98.1 \%$ had received training on dental treatment (Table 1).

Table 1. Distribution of socio-demographic data and comparison with adolescents' dental anxiety levels $(\mathrm{n}=213)$

\begin{tabular}{|c|c|c|c|c|}
\hline \multicolumn{5}{|c|}{ Data value } \\
\hline & \multirow{2}{*}{ Number (\%) } & \multirow{2}{*}{ Me. \pm S.D. } & \multicolumn{2}{|c|}{ Statistical Analyzes } \\
\hline & & & $\chi^{2}$ & $\mathrm{p}^{*}$ \\
\hline \multicolumn{5}{|l|}{ Sex } \\
\hline Boy & $94(44.1)$ & $9.00 \pm 3.36$ & \multirow[b]{2}{*}{16.907} & \multirow{2}{*}{$>0.05$} \\
\hline Girl & $119(55.9)$ & $8.70 \pm 2.74$ & & \\
\hline \multicolumn{5}{|l|}{ Groups of age } \\
\hline 13 & $76(35.7)$ & $8.50 \pm 2.91$ & \multirow{4}{*}{67.190} & \multirow{4}{*}{$=0.001$} \\
\hline 14 & $47(22.1)$ & $9.43 \pm 3.44$ & & \\
\hline 15 & $51(23.9)$ & $9.12 \pm 2.92$ & & \\
\hline 16 & $39(18.3)$ & $8.59 \pm 3.24$ & & \\
\hline \multicolumn{5}{|l|}{ Maternal age } \\
\hline $29-37$ & $63(29.6)$ & $8.57 \pm 3.28$ & \multirow{3}{*}{37.041} & \multirow{3}{*}{$<0.05$} \\
\hline $38-46$ & $121(56.8)$ & $9.18 \pm 3.07$ & & \\
\hline 47 and upper & $29(13.6)$ & $8.21 \pm 2.70$ & & \\
\hline \multicolumn{5}{|l|}{ Paternal age } \\
\hline 32-39 & $46(21.6)$ & $9.41 \pm 3.32$ & \multirow{3}{*}{53.234} & \multirow{3}{*}{$=0.001$} \\
\hline $40-47$ & $125(58.7)$ & $8.65 \pm 3.10$ & & \\
\hline 48 and upper & $42(19.7)$ & $8.93 \pm 2.81$ & & \\
\hline \multicolumn{5}{|c|}{ Maternal education level } \\
\hline$<1$ year & $6(2.8)$ & $7.67 \pm 3.39$ & \multirow{5}{*}{37.041} & \multirow{5}{*}{$<0.05$} \\
\hline 1-4 year & $70(32.9)$ & $8.60 \pm 3.10$ & & \\
\hline $5-8$ year & $48(22.5)$ & $9.75 \pm 2.89$ & & \\
\hline $9-12$ year & $56(26.3)$ & $9.45 \pm 3.15$ & & \\
\hline 13 year and upper & $33(15.5)$ & $7.39 \pm 2.68$ & & \\
\hline \multicolumn{5}{|c|}{ Paternal education level } \\
\hline$<1$ year & $5(2.3)$ & $9.40 \pm 4.10$ & \multirow{5}{*}{53.234} & \multirow{5}{*}{$=0.001$} \\
\hline 1-4 year & $54(25.4)$ & $8.78 \pm 3.41$ & & \\
\hline $5-8$ year & $32(15.0)$ & $8.16 \pm 3.11$ & & \\
\hline $9-12$ year & $69(32.4)$ & $9.61 \pm 3.10$ & & \\
\hline 13 year and upper & $53(24.9)$ & $8.38 \pm 2.51$ & & \\
\hline \multicolumn{5}{|l|}{ Family income } \\
\hline Low & $26(12.2)$ & $8.92 \pm 2.31$ & & \\
\hline Moderate & $178(83.6)$ & $9.03 \pm 3.18$ & 57.765 & $<0.001$ \\
\hline High & $9(4.2)$ & $5.56 \pm 0.53$ & & \\
\hline Previous application $t$ & ntist & & & \\
\hline Yes & $199(93.4)$ & $8.79 \pm 2.99$ & & \\
\hline No & $14(6.6)$ & $9.93 \pm 4.34$ & 29.380 & $=0.003$ \\
\hline Having negative expe & $\mathrm{n}$ the past & & & \\
\hline Yes & $27(12.7)$ & $9.89 \pm 2.93$ & 21711 & $<005$ \\
\hline No & $186(87.3)$ & $8.72 \pm 3.10$ & $21 . / 11$ & $<0.05$ \\
\hline Toothache & & & & \\
\hline Yes & $114(53.5)$ & $8.81 \pm 3.36$ & & \\
\hline No & $99(46.5)$ & $8.94 \pm 2.78$ & 20.010 & $>0.05$ \\
\hline Choosing a Dental Tr & Center & & & \\
\hline $\mathrm{PDC}$ & $20(9.4)$ & $6.65 \pm 2.68$ & 94.493 & $=0.003$ \\
\hline & & 247 & & \\
\hline
\end{tabular}




\begin{tabular}{ccc}
\hline CBDC & $41(19.2)$ & $8.80 \pm 3.30$ \\
PHDC & $16(7.5)$ & $8.94 \pm 3.75$ \\
SHDC & $76(35.7)$ & $9.00 \pm 2.93$ \\
T/RHDC & $33(15.5)$ & $8.82 \pm 3.10$ \\
UHDC & $27(12.7)$ & $10.26 \pm 2.36$ \\
Training regarding dental treatment & \\
Yes & $153(71.8)$ & $9.22 \pm 3.27$ \\
No & $60(28.2)$ & $8.50 \pm 4.12$ \\
\hline
\end{tabular}

*p<0.05. t: Independent sample t-test, F: One way ANOVA. Me.: Mean, S.D.: Standard Derivation. PDC: Private Dental Clinic, CBDC: Community Based Dental Clinic, PHDC: Private Hospital Dental Clinic, SHDC: State Hospital Dental Clinic, T/RHDC: Training and Research Hospital Dental Clinic, UHDC: University Hospital Dental Clinic.

The comparison of dental anxiety levels of adolescents according to sociodemographic data is presented in Table 1. According to the results of the chi-square test, a statistically significant difference $(\mathrm{p}<0.05)$ was found in the dental anxiety levels of the adolescents in terms of adolescents' age, maternal age, paternal age, maternal education level, paternal education level, family income, previous application to the dentist, having negative experience in the past, choosing a dental treatment center, and training regarding dental treatment (Table 1).

The average of the adolescents' dental anxiety level was $8.87 \pm 3.10$, and the average of the family's dental anxiety level was $8.97 \pm 3.24$. In addition, the average of perceived family support level by the adolescents was $28.84 \pm 7.04$. The average of the family assessment device subscale scores were problem solving $1.81 \pm 0.59$, communication $1.78 \pm 0.52$, roles $2.08 \pm 0.43$, affective responsiveness $1.84 \pm 0.55$, affective involvement $2.47 \pm 0.43$, behavior control $1.93 \pm 0.42$, and general functioning $1.84 \pm 0.45$. According the results of the FAD, it was stated that mean scores above 2.0 are indicative of a trend towards "unhealthy" in family functions. Accordingly, the family functions of the adolescents included in study were unhealthy only in terms of "roles" and "affective involvement", and healthy in terms of other variables. The results of the independent sample t-test regarding whether C-DAS, F-DAS, PFSS, and FAD subscale scores differ significantly according to gender were presented in Table-2. Adolescents' "Family Assessment Affective Responsiveness Subscale" scores differed significantly according to gender $(\mathrm{t}=2.288, \mathrm{p}<0.05$, Table 2$)$.

Table 2. The independent sample t-test results of A-DAS, F-DAS, PFSS, and FAD subscale scores by gender

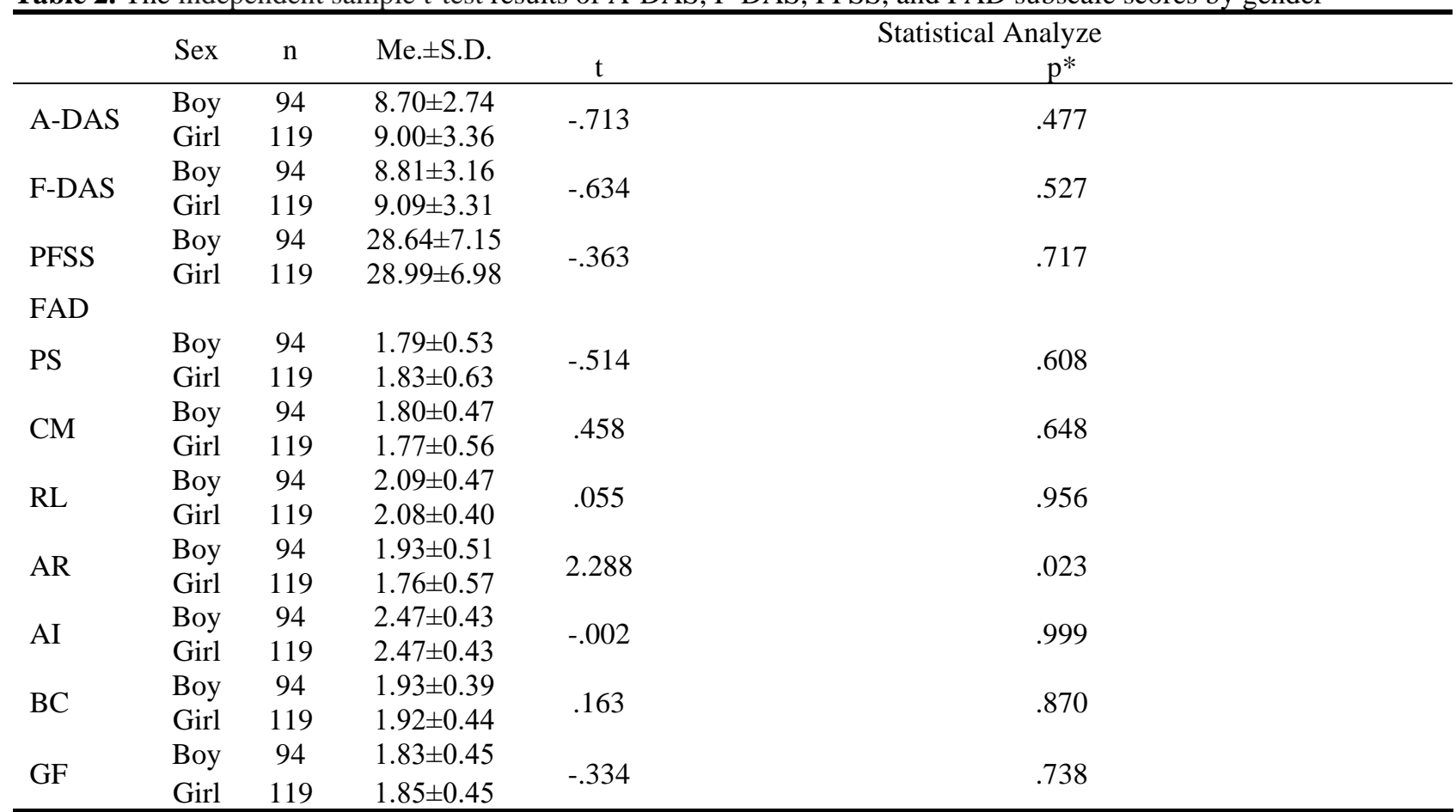

$* \mathrm{p}<0.05, \mathrm{t}$ : Independent sample t-test, Values are as given range (Mean \pm Standard Deviation). 
¥F-DAS: Family Dental Anxiety Scale.

§FSS: Perceived Family Support Scale.

\#FAD: Family Assessment Device Scale, PS: Problem Solving, CM: Communication, RL: Roles, AR: Affective Responsiveness, AI: Affective Involvement, BC: Behavior Control, GF: General Functioning.

The results of the correlation between adolescents' dental anxiety scale and sociodemographic data (adolescents' ages, maternal age, father's age, family income, maternal education level, paternal education level, previous admission to the dentist, having negative experience in the past, choosing a dental treatment center, training related to dental treatment, toothache) are presented below (Table 3). When the relationship between the dental anxiety levels of the adolescents and sociodemographic data was evaluated, a statistically significant positive correlation was found between the dental anxiety levels of the adolescents and the choice of a dental treatment center, and training regarding dental treatment (Table 3).

Table 3. Pearson correlations (rs) between A-DAS ${ }^{\dagger}$ and adolescents' sociodemographic data

\begin{tabular}{|c|c|c|c|c|c|c|c|c|c|c|c|c|c|}
\hline & A-DAS & Sex & A-Age & M-Age & P-Age & INC & MEL & PEL & PaTd & NEP & DTC & TRDT & T-Ache \\
\hline A-DAS & 1 & .05 & .03 & .00 & -.05 & -.12 & -.09 & .02 & -.09 & .13 & $.214 * *$ & $.173^{*}$ & -.02 \\
\hline Sex & & 1 & .11 & .07 & -.01 & -.08 & .01 & .00 & -.01 & -.12 & -.05 & -.05 & .08 \\
\hline A-Age & & & 1 & .09 & $.156^{*}$ & .11 & $.149 *$ & .03 & $-.143^{*}$ & -.10 & .01 & -.01 & $-.154 *$ \\
\hline M-Age & & & & 1 & $.577 * *$ & -.11 & .11 & -.04 & .11 & .01 & .06 & -.11 & $.180 * *$ \\
\hline P-Age & & & & & 1 & .01 & .10 & .10 & $.228 * *$ & .10 & -.10 & -.07 & .05 \\
\hline INC & & & & & & 1 & $.178 * *$ & .05 & -.10 & .01 & $-.155^{*}$ & -.12 & .03 \\
\hline MEL & & & & & & & 1 & .12 & $-.169 *$ & .07 & -.02 & $-.167 *$ & -.13 \\
\hline PEL & & & & & & & & 1 & -.07 & -.04 & -.06 & .01 & -.07 \\
\hline PaTd & & & & & & & & & 1 & .10 & .03 & $-.143 *$ & .13 \\
\hline NEP & & & & & & & & & & 1 & -.09 & .03 & .07 \\
\hline DTC & & & & & & & & & & & 1 & $-.144^{*}$ & .01 \\
\hline TRDT & & & & & & & & & & & & 1 & .00 \\
\hline T-Ache & & & & & & & & & & & & & 1 \\
\hline
\end{tabular}

The results of the correlation between adolescents' dental anxiety scale and family's dental anxiety scale, PFSS scores and sub-scale of FAD are presented below (Table 4). When the relationship between adolescents' dental anxiety levels and F-DAS, PFSS, and subscale scores of
FAD was evaluated, a statistically significant positive correlation was found between adolescents' dental anxiety levels and F-DAS mean scores and FAD general functions subscale mean scores (Table 4).

Table 4. Pearson correlations (rs) between A-DAS ${ }^{\dagger}$ and F-DAS $\ddagger$, PFSS $\S$, subscale scores of FAD\#

\begin{tabular}{|c|c|c|c|c|c|c|c|c|c|c|}
\hline & A-DAS & F-DAS & PFSS & PS & $\mathrm{CM}$ & RL & AR & AI & $\mathrm{BC}$ & GF \\
\hline A-DAS & 1 & $.346^{* *}$ & -.10 & .06 & .00 & .06 & .04 & -.10 & .11 & $.135^{*}$ \\
\hline F-DAS & & 1 & $-.194 * *$ & .07 & $.141 *$ & .13 & .12 & .12 & .13 & .03 \\
\hline PFSS & & & 1 & $-.178 * *$ & $-.158 *$ & $-.282 * *$ & -.08 & .01 & $-.169 *$ & $-.251 * *$ \\
\hline \multicolumn{11}{|l|}{ FAD } \\
\hline PS & & & & 1 & $.621 * *$ & $.519 * *$ & $.491 * *$ & $.154 *$ & $.489 * *$ & $.681 * *$ \\
\hline $\mathrm{CM}$ & & & & & 1 & $.567 * *$ & $.550 * *$ & $.312 * *$ & $.537 * *$ & $.706 * *$ \\
\hline RL & & & & & & 1 & $.469 * *$ & $.325 * *$ & $.528 * *$ & $.622 * *$ \\
\hline $\mathrm{AR}$ & & & & & & & 1 & $.409 * *$ & $.532 * *$ & $.655^{* *}$ \\
\hline AI & & & & & & & & 1 & $.207 * *$ & $.279 * *$ \\
\hline $\mathrm{BC}$ & & & & & & & & & 1 & $.601 * *$ \\
\hline
\end{tabular}


$* \mathrm{p}<0.05, * * \mathrm{p}<0.01$

${ }^{\dagger}$ A-DAS: Adolescent Dental Anxiety Scale.

F-DAS: Family Dental Anxiety Scale.

${ }^{\S}$ PFSS: Perceived Family Support ScalE.

${ }^{\#}$ FAD: Family Assessment Device Scale, PS: Problem Solving, CM: Communication, RL: Roles, AR: Affective Responsiveness, AI: Affective Involvement, BC: Behavior Control, GF: General Functioning.

In the first multiple logistic regression analysis, the extent to which sociodemographic data predicted dental anxiety levels in adolescents was examined. This regression analyses showed that maternal education level, previous application to the dentist, having negative experience in the past, choosing a dental treatment center, and training related to dental treatment were associated with adolescents' dental anxiety levels $\left(\mathrm{F}_{(12}\right.$, $\left.{ }_{200}=2.855, \mathrm{p}<0.001\right)$ and the independent variables in the model explained $14.6 \%$ of the unique variance in the adolescents' dental anxiety levels. According to the standardized regression coefficients, the order of importance of predictive variables on adolescents' dental anxiety levels is training related to dental treatment $(\beta=-0.207)$, choosing a dental treatment center $(\beta=0.198)$, having negative experience in the past $(\beta=0.191)$, previous application to the dentist $(\beta=-0.171)$, and maternal education level $(\beta=-0.143)$. Considering the significance tests of the regression coefficients, it was seen that only training related to dental treatment, choosing a dental treatment center, having negative experience in the past, previous application to the dentist, and maternal education level $(\mathrm{p}<0.05)$ were significant predictors on the adolescents' dental anxiety levels (Table 5).

Table 5. The multiple regression analysis results between A-DAS ${ }^{\dagger}$ and adolescents’ sociodemographic data

\begin{tabular}{|c|c|c|c|c|c|c|c|}
\hline & \multicolumn{2}{|c|}{ Unstandardized Coefficients } & \multirow{2}{*}{$\begin{array}{c}\text { Standardized } \\
\text { Coefficients } \\
\beta \\
\end{array}$} & \multirow[t]{2}{*}{$\mathrm{t}$} & \multirow{2}{*}{$\mathrm{p}^{*}$} & \multicolumn{2}{|c|}{ Correlations } \\
\hline & $\mathrm{B}$ & Std. Error & & & & Zero-order & Partial \\
\hline (Constant) & 2.963 & 3.766 & & .787 & .432 & & \\
\hline Sex & .399 & .418 & .064 & .956 & .340 & .048 & .067 \\
\hline A-Age & .101 & .192 & .037 & .527 & .599 & .026 & .037 \\
\hline M-Age & -.005 & .063 & -.008 & -.080 & .937 & -.021 & -.006 \\
\hline P-Age & -.004 & .068 & -.006 & -.055 & .956 & -.025 & -.004 \\
\hline INC & -.818 & .538 & -.105 & -1.521 & .130 & -.119 & -.107 \\
\hline MEL & -.380 & .185 & -.143 & -2.053 & .041 & -.088 & -.144 \\
\hline PEL & .128 & .177 & .049 & .724 & .470 & .015 & .051 \\
\hline PaTd & -2.126 & .886 & -.171 & -2.400 & .017 & -.091 & -.167 \\
\hline NEP & 1.777 & .625 & .191 & 2.843 & .005 & .126 & .197 \\
\hline DTC & .408 & .139 & .198 & 2.930 & .004 & .214 & .203 \\
\hline TRDT & 1.421 & .471 & .207 & 3.019 & .003 & .173 & .209 \\
\hline T-Ache & -.204 & .430 & -.033 & -.476 & .635 & -.021 & -.034 \\
\hline
\end{tabular}

*p<0.05. $\mathrm{R}=0.382, \mathrm{R}^{2}=0.146$, Adjusted $\mathrm{R}^{2}=0.01, \mathrm{~F}_{(12-200)}=2.855, \mathrm{p}<0.001$.

$\dagger$ A-DAS: Adolescent Dental Anxiety Scale (Dependent variable).

Socio-demographic data (A-Age: Adolescents' age, M-Age: Maternal age, P-Age: Paternal age, INC: Family income, MEL: Maternal education level, PEL: Paternal education level, PaTd: Previous application to the dentist, NEP: Having negative experience in the past, DTC: Choosing a dental treatment center, TRDT: Training related to dental treatment, T-Ache: Toothache).

In the second multiple logistic regression analysis, the extent to which F-DAS, PFSS and FAD sub-scale scores predicted dental anxiety levels in adolescents were examined. This regression analysis showed that F-DAS score, and sub-scale scores FAD (communication, affective involvement and general functions) were associated with adolescents' dental anxiety levels, and the independent variables in the model explained $20.4 \%$ of the unique variance in the adolescents' dental anxiety levels. According to the standardized regression coefficients, the order of importance of predictive variables on adolescents' dental anxiety levels were F-DAS scores $(\beta=0.401)$, FAD-General functions $(\beta=0.395)$, FAD-Communication $(\beta=-0.229)$, and FADAffective involvement $(\beta=-0.158)$. Considering the significance tests of the regression coefficients, it was seen that only family's dental anxiety level, and family functions, such as general functions, communication, and affective involvement 
$(\mathrm{p}<0.05)$ were significant predictors on the

adolescents' dental anxiety levels (Table 6).

Table 6. The multiple regression analysis results between A-DAS $\uparrow$ and F-DAS $\uparrow$, PFSS $\S$ and subscale scores of FAD\#

\begin{tabular}{|c|c|c|c|c|c|c|c|}
\hline & \multicolumn{2}{|c|}{ Unstandardized Coefficients } & \multirow{2}{*}{$\frac{\text { Standardized Coefficients }}{\text { B }}$} & \multirow{2}{*}{$\mathrm{t}$} & \multirow{2}{*}{$\mathrm{p}^{*}$} & \multicolumn{2}{|c|}{ Correlations } \\
\hline & $\mathrm{B}$ & Std. Error & & & & Zero-order & Partial \\
\hline (Constant) & 5.957 & 1.853 & & 3.215 & .002 & & \\
\hline F-DAS & .383 & .063 & .401 & 6.070 & .000 & .346 & .392 \\
\hline PFSS & .014 & .030 & .032 & .467 & .641 & -.101 & .033 \\
\hline \multicolumn{8}{|l|}{ FAD } \\
\hline PS & -.185 & .474 & -.035 & -.392 & .696 & .064 & -.027 \\
\hline $\mathrm{CM}$ & -1.361 & .574 & -.229 & -2.373 & .019 & .004 & -.164 \\
\hline RL & -.161 & .629 & -.022 & -.257 & .798 & .059 & -.018 \\
\hline AR & -.430 & .511 & -.076 & -.842 & .401 & .039 & -.059 \\
\hline AI & -1.143 & .516 & -.158 & -2.214 & .028 & -.104 & -.154 \\
\hline $\mathrm{BC}$ & .397 & .622 & .054 & .637 & .525 & .113 & .045 \\
\hline GF & 2.728 & .804 & .395 & 3.394 & .001 & .135 & .232 \\
\hline
\end{tabular}

*p<0.05. $R=0.452, \mathrm{R}^{2}=0.204$, Adjusted $\mathrm{R}^{2}=0.17, \mathrm{~F}_{(9-203)}=5.786, \mathrm{p}<0.001$.

${ }^{\dagger}$ A-DAS: Adolescent Dental Anxiety Scale (Dependent variable).

F-DAS: Family Dental Anxiety Scale.

SPFSS: Perceived Family Support Scale.

"FAD: Family Assessment Device Scale, PS: Problem Solving, CM: Communication, RL: Roles, AR: Affective Responsiveness, AI: Affective Involvement, BC: Behavior Control, GF: General Functioning.

\section{DISCUSSION}

Excessive dental fear and anxiety is a universal problem affecting the great majority of the population. ${ }^{24}$ It was reported in previous studies that the dental anxiety in childhood continues in adult period, and therefore, determining dental anxiety at an early stage is important. ${ }^{25,26}$

Although it was reported that gender has an effect on dental anxiety levels, and in general, females have higher levels of dental anxiety than males ${ }^{27,28}$, there are several other studies reporting that dental anxiety is not gender-related. ${ }^{5,8,29}$ Foloyan et $a .^{5}$ reported that gender alone is not effective on dental anxiety; however, it is also known that it may cause a predisposition to dental anxiety by interacting with other variables. We found that in adolescents, gender differences in the report of dental anxiety were not as robust as in some other studies, and indeed non-significant in the present study. The specific age cohorts in the current study may have affected these results.

The effect of close surroundings, especially that of the family is important in children's behaviors in dental settings. ${ }^{30,31}$ In the study of Neverlien, it was reported that there was a positive correlation between the socioeconomic status and cultural structures of the family and the behavior of children in clinics. ${ }^{32}$ Tuuti ${ }^{33}$ reported that children between the ages of 7 and 10 who had fathers with high educational status exhibited better and harmonious behaviors during dental treatments. Stabholz and Peretz ${ }^{34}$ reported that people with high levels of education had developed the ability to deal with stressful conditions more easily. However, there are also several studies that did not report any relation between the level of education and dental anxiety. ${ }^{35,36}$

When the relation between the income status of the family and dental anxiety level was evaluated, the lowest dental anxiety in adolescents was determined in high-income families. Similarly, Wright and Alpern ${ }^{37}$ found that families with high socioeconomic status showed better co-operation during dental treatment for their 3-5-year-old children. Higher income families pay more attention to oral and dental health; hence, one can talk about more time and budget allocation. According to the results of this study, the dental anxiety level was found to be higher in the adolescents with mothers having low education levels and the level of dental anxiety was higher in the adolescents belonging to low-income families.

There is no consensus on the relations between children and their parents' dental anxiety. Wu et al. ${ }^{38}$ reported a weak relation between the dental anxiety of children and their parents, and for 
this reason, they suggested that children might not have learned dental anxiety from their parents. However, in some studies, the mother's dental anxiety affected the dental anxiety of children because children spent longer time with their mothers during the period of social learning, and it was suggested that it adversely affected children's behaviors during dental treatments. ${ }^{39,40}$ One of the most interesting research findings was that, when accounted for separately and concurrently, fathers' but not mothers' dental fear predicts adolescent dental fear/anxiety. ${ }^{41}$ In this study, a relation was not detected between parents' dental anxiety and their adolescents' dental anxiety. Additional research is needed to comprehensively understand the parents' dental anxiety role in adolescens' dental anxiety.

It is often stated that the primary cause of anxiety is negative dental treatment experiences, and numerous studies support the importance of conditioning in anxiety. ${ }^{42,43}$ However, repeated asymptomatic visits play a prophylactic role for anxiety, and children participating in preventive programs show lower levels of fear symptoms. Nicolas et al. ${ }^{44}$ state that children who have had their teeth filled before have less fear than those who have never had dental treatment. The first dentist appointment is an important factor in how the child will take a position regarding a dentist and dental treatments in the future. Patients should be encouraged to ask questions about their treatment and be fully informed about what to do before starting the procedure, and also, during the procedure. According to results of a study by Töredi et al. ${ }^{45}$, it can be said that the disclosure of the treatment is important for reducing the anxiety of the children. Similarly, the dental anxiety level of adolescents who have received information related to their dental treatment was lower than the dental anxiety level of uninformed adolescents in this study. In previous studies, it was found that there were no significant relations between anxiety and restorative treatment history in 5-year-old children; however, there was a significant relation between anxiety and restorative treatment experience in adolescents between 12 and 15 years of age. ${ }^{46,47}$ In this study, dental anxiety levels were lower in adolescents who had a previous dental examination and higher in adolescents who had negative experiences during their dental treatments in the past.

Dental health center ambience can play a significant role in initiating dental anxiety. ${ }^{48}$ The office atmosphere can be made calm and unthreatening. Importantly, anxious patients should not be made to wait too long so that they have less time to absorb negative experiences; additionally, a longer waiting time gives them time to recall the threatening stimuli. ${ }^{49}$ In a previous study by Fux-Noy et al. ${ }^{50}$, dental anxiety was significantly higher in patients who had longer waiting time prior to treatment. In this study, the dental anxiety of adolescents applied to a state hospital was found to be higher due to the atmosphere and the long waiting time in these institutions.

This is truly the first study to address the unique roles of family functionality in dental anxiety especially in a sample of adolescents. It was reported that preschool anxiety had effects on the way the family functioned, especially on the parental compliance, and thus, highlighting family dysfunction acierated with early anxiety. ${ }^{47}$ The study provides support for this phenomenon for dental anxiety occurring not only in childhood, but also, in adolescence. In the current study, a positive and statistically significant relation was detected between communication, affective involvement and general functions scores of the families and the dental anxiety levels of the adolescents. The dental anxiety levels of the adolescents of families with disrupted family functionality were found to be higher. The communication and role distribution within the family, problem-solving skills of the family, and conflicts in exhibiting due attention cause behavioral and emotional reflections in children and adolescents. Being less aware of the problems within the family or having difficulties in talking about such problems increase the anxiety levels of children and adolescents.

\section{Limitations}

There are limitations to the study. Firstly, the scales used in the study were filled based on the individuals' self-assessment. For this reason, the 
biases people can make while evaluating themselves cannot be controlled. The biases and evaluation mistakes that may be made by the individuals may have affected the results of the study. Secondly, the findings of the study may not be generalizable to older adolescents as differences in psychological and physical status exist between early adolescents and late adolescents. Additional research is needed to comprehensively understand factors affecting dental anxiety in adolescants.

\section{CONCLUSIONS}

When the reasons underlying dental anxiety are evaluated, the patient should be considered in a holistic manner. Determining the dental anxiety/fear level will be the first step in establishing cooperation and a healthy dentistpatient relation in the treatment process. Family functionality plays a role in dental anxiety development in adolescents. In this sense, activities and trainings should be organized for parents to acquire the skill of detecting problems in their families and talking about them.

\section{ACKNOWLEDGMENT}

No funding was received for this study.

\section{CONFLICT OF INTEREST}

The authors declare that they have no conflict of interest.

\section{$\ddot{O} Z$}

Amaç: Dental kaygl, ă̆ız să̆lığının korunmasında uzun vadeli etkilerle birlikte yararlanılan diş tedavisinin sıklı̆̆ını belirler. Bu çalışmanın amacı, sosyodemografik veriler, ebeveynlerin dental kaygl düzeyleri, aile işlevselliği, algılanan aile desteği ve diğer ilişkili faktörlerin ergen dental kaygısı üzerindeki etkilerini araştırmaktır. Gereç ve Yöntemler: Çocuk Diş Kliniği'ne başvuran 213 ergen ve ebeveyn çalışmaya dahil edildi ve sosyodemografik verileri kaydedildi. Dental kaygiyı belirlemek için, ergenlere ve ebeveynlerine Corah Dental Anksiyete Ölçeği ve ergenlerin algllanan aile desteğini belirlemek için, ergenlere Algılanan Aile Desteği Ölçeği uyguland. Aile işlevselliği ile ilgili olarak, ebeveynler Aile Değerlendirme Ölçeği'ni cevaplad. Bulgular: Ergenlerin ortalama dental kaygl düzeyi $8.87 \pm$ 3.10'dur. Aile işlevleri roller ve duygusal katılim açısından sağllksızdl. Çoklu regresyon analizine göre, dental kaygı düzeylerinin yordayıcılarl; aile işlevselliği, annenin eğitim düzeyi, daha önce diş hekimine başvurma, geçmişte olumsuz deneyime sahip olma, diş tedavi merkezi seçimi ve dis tedavisi ile ilgili eğitimdir. Sonuçlar: Klinisyenler, sosyo-kültürel özelliklerin, aile işlevselliğinin ve aile desteğinin, dental kaygıyı etkileyebileceğini ve fiziksel çevrenin iyileştirilmesinin ergenlerin diş tedavisi sirasinda dental kaygıyı azaltmada etkili olabileceğini göz önünde bulundurmalıdır. Anahtar Kelimeler: Ergenler; diş kaygısı, aile işlevselliği, algılanan aile desteği, sosyodemografik faktörler.

\section{REFERENCES}

1. Folayan MO, Idehen EE, Ojo OO. The modulating effect of culture on the expression of dental anxiety in children: a literature review. Int $\mathrm{J}$ Paediatr Dent 2004;14:241-245.

2. Klingberg G, Raadal M, Arnrup K. Dental fear and behavior management problems. In: Koch G, Poulsen $\mathrm{S}$ (eds). Paediatric dentistry: A clinical approach. WileyBlachwell, 2009.

3. Gordon D, Heimberg RG, Tellez M, Ismail AI. A critical review of approaches to the treatment of dental anxiety in adults. J Anxiety Disord 2013;27:365-378.

4. Shim Y-S, Kim A-H, Jeon E-Y, An S-Y. Dental fear $\&$ anxiety and dental pain in children and adolescents; a systemic review. J Dent Anesth Pain Med 2015;15:5361.

5. Folayan MO, Idehen EE, Ufomata D. The effect of sociodemographic factors on dental anxiety in children seen in a suburban Nigerian hospital. Int J Paediatr Dent 2003;13:20-26.

6. Lee CY, Chang YY, Huang ST. Prevalence of dental anxiety among 5- to 8-yearold Taiwanese children. J Public Health Dent 2007;67:36-41.

7. Skaret E, Raadal M, Berg E, Kvale G. Dental anxiety among 18-yr-olds in Norway. Prevalence and related factors. Eur J Oral Sci 1998;106:835-843.

8. Doğan MC, Şeydaoğlu G, Uğuz S, Inanç BY. The effect of age, gender and socioeconomic factors on perceived dental anxiety determined by a modified scale in children. Oral Health Prev Dent 2006;4:235-241.

9. Cuthbert MI, Melamed BG. A screening device: children at risk for dental fears and management problems. J Dent Child 1982;49:432-436. 
10. Majstorovic M, Veerkamp JSJ. Developmental changes in dental anxiety in a normative population of Dutch children. Eur J Paediatr Dent 2005;6:30-34.

11. Epstein NB, Levin S, Bishop DS. The family as a social unit. Can Fam Physician 1976;22:53-55.

12. Golden LB. Managing maladaptive behavior in ill children through family interventions. J Sch Health 1984;54:389-391.

13. Capps L, Sigman M, Sena R, Henker B, Whalen C. Fear, Anxiety and Perceived Control in Children of Agorafobik Parents. J Child Psychol Psychiatry 1996;37:445-452.

14. Ginter EJ, Lufi D, Dwinell Pl. Loneliness, perceived social support, and anxiety among Israeli adolescents. Psychol Rep 1996;79:335-341.

15. Gao X, Hamzah SH, Yiu CK, McGrath C, King NM. Dental fear and anxiety in children and adolescents: qualitative study using YouTube. J Med Internet Res 2013;15:e29.

16. Klingberg G, Broberg AG. Dental fear/anxiety and dental behaviour management problems in children and adolescents: a review of prevalence and concomitant psychological factors. Int J Paediatr Dent 2007;17:391406.

17. Buchanan H, Niven N. Validation of a Facial Image Scale to assess child dental anxiety. Int J Paediatr Dent 2002;12:47-52.

18. Coxon J, Hosey M, Newton J. How does dental anxiety affect the oral health of adolescents? A regression analysis of the Child Dental Health Survey 2013. Br Dent J 2019;227:823-828.

19. Milgrom P, Vignehsa H, Weinstein P. Adolescent dental fear and control: prevalence and theoretical implications. Behav Res Ther 1992;30:367-373.

20. Şeydaoğlu G, Doğan M, Uğuz S, Inanç B, Diler R. Reliability and Validity of the Turkish Version of "Dental Subscale of the Children's Fear Survey Schedule" and the Frequency and Risk Factors of Dental Fear in Children. J Ege Univ Fac Dent 2006;27:31-38.

21. Epstein NB, Baldwin LM, Bishop DS. The McMaster family assessment device. J

22. Marital Fam Ther 1983;9:171-180.

23. Öngel Atar A, Yalçin Ö, Uygun E, Çiftçi Demirci A, Erdoğan A. The Assessment of Family Functions, Dyadic Adjustment, and Parental Attitude in Adolescents with Substance Use Disorder. Noro Psikiyatr Ars 2016;53:38-44.
24. Eskin M. Reliability of the Turkish version of the perceived social support from friends and family scales, scales for interpersonal behavior and suicide probability scale. J Clin Psychol 1993;49:515-522.

25. Eli I, Baht R, Blacher S. Prediction of success and failure of behavior modification as treatment for dental anxiety. Eur J Oral Sci 2004;112:311-315.

26. Smyth JS. Some problems of dental treatment. Part 1. Patient anxiety: some correlates and sex differences. Aust Dent J 1993;38:354-359.

27. Skaret E, Raadal M, Berg E, Kvale G. Dental anxiety among 18-yr-olds in Norway. Prevalence and related factors. Eur J Oral Sci 1998;106:835-843.

28. Kothari S, Gurunathan D. Factors influencing anxiety levels in children undergoing dental treatment in an undergraduate clinic. J Family Med Prim Care 2019;8:2036-2041.

29. Özlek E, Yıldırım A, Koç A, Boysan M. Sociodemographic determinants of dental anxiety and fear among college students. Eastern J Med 2019;24:169175.

30. Wogelius P, Poulsen S, Sørensen HT. Prevalence of dental anxiety and behavior management problems among six to eight years old Danish children. Acta Odontol Scand 2003;61:178-183.

31. Brown DF, Wright FA, McMurray NE. Psychological and behavioral factors associated with dental anxiety in children. J Behav Med 1986; 9:213218.

32. Freeman RE. Dental anxiety: A multifactorial aetiology. Br Dent J 1985; 159:406-408.

33. Neverlien PO. Assessment of a single-item dental anxiety question. Acta Odontol Scand 1990;48:365-369. 34. Tuuti H. Socio-economic, psychological and historical background of dental fears of 7-10-year-old in Povaniemi, Finland. Proc Finn Dent Soc 1984;80:87.

35. Stabholz A, Peretz B. Dental anxiety among patients prior to different dental treatments. Int Dent $\mathrm{J}$ 1999;49:90-94.

36. Hakeberg M, Berggren U, Carlsson SG. Prevalence of dental anxiety in an adult population in a major urban area in Sweden. Community Dent Oral Epidemiol 1992;20:97-101.

37. Kleinknecht RA, Thorndike RM, McGlynn FD, Harkavy J. Factor analysis of the dental fear survey with cross-validation. J Am Dent Assoc 1984;108:59-61. 
38. Wright GZ, Alpern GD. Variables influencing children's cooperative behavior at the first dental visit. J Dent Child 1971;38:124-128.

39. Wu L, Gao X. Children's dental fear and anxiety: exploring family related factors. BMC Oral Health 2018;18:100.

40. Folayan MO, Adekoya-Sofowora CA, Otuyemi O, Ufomata D. Parental anxiety as a possible predisposing factor to child dental anxiety in patients seen in a suburban dental hospital in Nigeria. Int J Paediatr Dent 2002;12:255-259.

41. Gershen JA. Maternal influence on the behavior patterns of children in the dental situations. J Dent Child 1976;43:28-32.

42. McNeil DW, Randall CL, Cohen LL, et al. Transmission of dental fear from parent to adolescent in an Appalachian sample in the USA. Int J Paediatr Dent 2019;29:720-727.

43. Diaz MC, Crego A, Armfield JM, Maroto MR. Assessing the relative efficacy of cognitive and noncognitive factors as predictors of dental anxiety. Eur $\mathbf{J}$ Oral Sci 2012;120:82-88.

44. Locker D, Shapiro D, Lindell A. Negative dental experiences and their relationship to dental anxiety. Community Dent Health 1996;13:25-37.

45. Nicolas E, Bessadet M, Collado V, Carrasco P, Rogerlero1 V, Hennequin M. Factors affecting dental fear in French children aged 5-12 years. Int J Paediatr Dent 2010;20:366-363.
46. Töredi E, Erdem Y. Dental Anxiety Levels and Affecting Factors in 7-14 Years Old Children. ARC J Nurs Healthcare 2017;3:1-10.

47. Milsom KM, Tickle M, Humphris GM, Blinkhorn AS. The relationship between anxiety and dental treatment experience in 5-year-old children. Br Dent $\mathbf{J}$ 2003; 194:503-506.

48. Towe-Goodman NR, Franz L, Copeland W, Angold A, Egger H. Perceived family impact of preschool anxiety disorders. J Am Acad Child Adolesc Psychiatry 2014;53:437-446.

49. Halvari AEM, Halvari H, Deci EL. The Roles of Patients' Authenticity and Accepting External Influence, and Clinicians' Treatment Styles in Predicting Patients' Dental Anxiety and Avoidance of Dental Appointments. Eur J Psychol. 2020;16:45-61.

50. Appukuttan DP. Strategies to manage patients with dental anxiety and dental phobia: literature review. Clin Cosmet Investig Dent 2016;8:35-50.

51. Fux-Noy A, Zohar M, Herzog K, et al. The effect of the waiting room's environment on level of anxiety experienced by children prior to dental treatment: a case control study. BMC Oral Health 2019;19:294. 